Penelitian

\title{
Kajian Epidemiologi Infeksi Bovine Viral Diarrhea (BVD) pada Sapi Perah di Kabupaten Sleman Yogyakarta
}

\author{
Roza Azizah Primatika ${ }^{1^{*}}$, Bambang Sumiarto', Dyah Ayu Widiasih', Yatri Drastini' \\ ${ }^{1}$ Departemen Kesehatan Masyarakat Veteriner, Fakultas Kedokteran Hewan, \\ Universitas Gadjah Mada, Indonesia \\ *Penulis untuk korespondensi: roza.azizah@ugm.ac.id \\ Diterima 13 Februari 2019, Disetujui 15 November 2019
}

\begin{abstract}
ABSTRAK
Sapi perah merupakan hewan ruminansia yang menghasilkan susu untuk konsumsi sehari hari masyarakat Indonesia karena mengandung sumber kalsium yang baik bagi tubuh. Namun, saat ini kendala yang dihadapi oleh peternak adalah menurunnya produksi susu sapi perah sehingga menyebabkan kerugian ekonomi yang cukup besar. Salah satu penyakit yang menyebabkan penurunan produksi susu pada sapi perah adalah Bovine Viral Diarrhea (BVD). Bovine Viral Diarrhea telah menyebar di seluruh dunia termasuk di Indonesia. Pemerintah Indonesia belum menetapkan kebijakan vaksinasi BVD. Tujuan penelitian ini adalah untuk mengetahui seroprevalensi dan faktor resiko mengenai infeksi Bovine Viral Diarrhea (BVD) di tingkat peternak di Kabupaten Sleman Yogyakarta. Metode penelitian ini adalah dengan melakukan wawancara terhadap peternak melalui kuesioner dan metode sampling yang digunakan pada penelitian ini adalah teknik sampling tahapan ganda serta dianalisis secara univariat dan bivariat. Sampel penelitian ini adalah 96 peternak terpilih yang memiliki sapi perah dan dilakukan pengujian Bovine Viral Diarrhea (BVD) dengan metode Enzyme-linked Immunosorbent Assay (ELISA) antibodi. Berdasarkan analisis univariat, diperoleh seroprevalensi penyakit BVD pada sapi perah sebesar 56,25\%. Berdasarkan analisis bivariate, hasil yang diperoleh adalah tidak terdapat hubungan antara variabel yang diuji dengan adanya penyakit BVD pada sapi perah di Kabupaten Sleman, yang ditunjukkan dengan nilai p_value $>0.05$.

Kata kunci: Bovine Viral Diarrhea (BVD), enzyme-linked immunosorbent assay (ELISA), analisis univariat, analisis bivariat
\end{abstract}

\begin{abstract}
Dairy cows are ruminant animals that produce milk for the daily consumption of the Indonesian people because they contain good sources of calcium for the body. However, currently the constraints faced by farmers are the decrease in dairy cow milk production which causes considerable economic losses. One of the diseases that causes a decrease in milk production in dairy cows is Bovine Viral Diarrhea (BVD). Bovine Diarrhea Viral has spread throughout the world including in Indonesia. The Indonesian government has not yet established a BVD vaccination policy. The purpose of this study was to determine the description of categorical variables regarding Bovine Viral Diarrhea (BVD) infection at the farm in Sleman Regency, Yogyakarta. This research method is to interview farmers through questionnaires and the sampling method used in this study is a double stage sampling technique and analyzed descriptively. The sample of this study were 96 selected breeders who had dairy cows and were tested for Bovine Viral Diarrhea (BVD) using Enzyme-linked Immunosorbent Assay (ELISA) antibodies. The results of univariate analysis is seroprevalence of BVD in dairy cows $56,25 \%$. The results of bivariate analysis is no correlation between variables and BVD disease in dairy cows in Sleman Subdistrict. The results show that p_value $>0.05$.
\end{abstract}

Keywords: Bovine Viral Diarrhea (BVD), enzyme-linked immunosorbent assay (ELISA), univariate analysis, bivariate analysis 


\section{PENDAHULUAN}

Bovine Viral Diarrhea (BVD) merupakan salah satu penyakit infeksi yang menyerang sapi perah dan menyebabkan kerugian ekonomi (Houe 2003). Menurut Weersink et al (2002) kerugian ekonomi yang terjadi akibat infeksi Bovine Viral Diarrhea (BVD) pada sapi perah berupa penurunan produksi dan reproduksi. Populasi sapi di Indonesia mencapai 544.791 ekor (BPS 2018). Yogyakarta merupakan salah satu wilayah yang memiliki populasi sapi sebesar 4.181 ekor (BPS 2018) yang tersebar di 5 kabupaten yaitu Kabupaten Sleman, Bantul, Gunungkidul, Kulonprogo, dan Kota Yogya. Salah satu wilayah dengan produksi susu sapi cukup tinggi berada di Kabupaten Sleman. Kabupaten Sleman merupakan satu-satunya kabupaten penghasil susu segar di Provinsi Daerah Istimewa Yogyakarta. Jumlah ternak sapi perah di Kabupaten Sleman pada tahun 2015 adalah \pm 3.748 ekor dan produksi susu yang dihasilkan mencapai 3.609,21 ton (BPS 2015). Kajian epidemiologi menunjukkan bahwa terdapat beberapa kerugian akibat infeksi BVDV yaitu menurunnya kesehatan dan kinerja reproduksi sapi. Infeksi BVDV selalu terkait dengan peningkatan risiko mastitis klinis, retensi plasenta, terapi perangsang estrus dan calving interval (Niskanen et al. 1995).

BVD adalah penyakit infeksius pada sapi yang disebabkan oleh Bovine Viral Diarrhea Virus (BVDV) yang merupakan virus ssRNA dan termasuk dalam genus Pestivirus pada famili Flaviviridae. Manifestasi klinis dari penyakit ini dapat berupa abortus, kegagalan reproduksi, imunosupresi, gangguan pertumbuhan, mucosal disease (MD), hingga infeksi sekunder. Transmisi utama dalam suatu peternakan yaitu melalui kontak langsung dengan hewan yang mengalami infeksi persisten (persistent infection, $\mathrm{PI}$ ), yang diakibatkan oleh infeksi pada fetus pada kebuntingan 40-125 hari (Fray et al. 2000; Lindberg and Houe 2005; Houe et al. 2006; Lanyon et al. 2014; Marques et al. 2016)

Gejala klinis BVD tergantung pada kondisi kesehatan hospes, status reproduksi, strain virus dan ada tidaknya infeksi sekunder (Ridpath 2003). Penyakit BVD menyebabkan terjadinya kawin berulang, kematian fetus, abortus mumifikasi fetus, kelahiran mati, immunosupresif, kelahiran cacat, berat lahir pedet rendah dan pedet Persistently Infection (Baker 1990; Baker 1995). Virus BVD dapat mengakibatkan dua infeksi yaitu infeksi persisten (Persistently Infection/PI) atau infeksi sementara (Transiently Infection/TI). Individu PI berasal dari pedet yang dilahirkan dari induk yang terinfeksi virus BVD NCP pada kebuntingan 40-125 hari (Fray et al. 2000). Sapi PI ini akan menularkan virus BVD selama hidupnya (Baker 1995). Transiently Infection (TI) adalah sapi yang mengalami infeksi akut dan mampu menyebabkan respon kekebalan (Rüfenacht et al. 2001). Pemerintah Indonesia saat ini belum menetapkan kebijakan program vaksinasi BVD. Sapi impor berupa sapi bakalan, sapi induk dan sapi bibit kemungkinan mendapatkan vaksinasi BVD di negara asal. Penelitian sebelumnya dengan metode uji ELISA antibodi terhadap serum sapi dari daerah Jawa Tengah, Jawa Timur dan Yogyakarta menunjukkan hasil bahwa infeksi BVD berasal dari infeksi alami dan bukan akibat dari vaksinasi (Swasthikawati 2015).

Penelitian ini bertujuan untuk mengetahui seroprevalensi dan faktor resiko penyakit BVD pada tingkat Peternak di Kabupaten Sleman Yogyakarta.

\section{BAHAN DAN METODE}

Penelitian ini menggunakan metode kajian lintas seksional untuk mengetahui seroprevalensi dan asosiasi antara variabel penelitian dan hasil pengujian Enzyme-linked Immunosorbent Assay (ELISA) antibodi BVD di tingkat peternak sapi perah di Kabupaten Sleman.

Penelitian dilakukan dengan mengumpulkan data primer dan data sekunder. Data primer adalah data yang diperoleh secara langsung dari peternak yang berupa sampel darah sapi pada peternakan tersebut. Pada saat pengambilan darah dilakukan pemasangan identitas ternak yang disesuaikan dengan kode tabung serum dan kode kuisioner. Data sekunder adalah data yang diperoleh dari Badan Pusat Statistik, Balai Besar Veteriner Wates dan Dinas Pertanian, Perikanan dan Kehutanan Kabupaten Sleman.

Penelitian ini menggunakan sapi perah di Kabupaten Sleman sebagai unit yang diamati. Pengambilan sampel dilakukan dengan menggunakan metode sampling tahapan ganda. Kecamatan, desa dan peternak dipilih dengan metode pengambilan sampel acak terencana secara acak proporsional. Sampel yang terpilih adalah 384 ekor sapi perah dengan umur lebih dari 6 bulan dan berasal dari 96 peternak, sekaligus dilakukan pengamatan kondisi ternak dan kandang.

Pengujian titer antibodi Bovine Viral Diarrhea dengan menggunakan Enzyme-linked Immunosorbent Assay (ELISA) antibodi (ID Screen ${ }^{\circledR}$ BVD p80 Antibody Competition, IDvet France). Antibodi dideteksi dengan kompetitif ELISA secara kualitatif. 
Sensitivitas dan spesifisitas kit ELISA antibodi berdasarkan informasi dari brosur masing-masing 100\% dan $100 \%$.

Kit ELISA antibodi terdiri dari beberapa komponen. Komponen ELISA antibodi terdiri dari micro assay plate (480 sumuran yang dindingnya sudah dilapisi antigen $\mathrm{p} 80$ ), larutan konjugat, kontrol positif, kontrol negatif, dilution buffer 19, cairan pencuci, substrat Tetra Methyl Benzidine (TMB) dan stop solution.

\section{Besaran Sampel}

Besaran sampel pada kajian lintas seksional untuk mengetahui seroprevalensi dihitung menggunakan rumus (Martin et al. 1987):

$$
n=\frac{4 P Q}{L^{2}}
$$

Keterangan:

$\mathrm{n}$ = besaran sampel yang digunakan;

$\mathrm{P}=$ Prevalensi seropositif BVD;

$\mathrm{Q}=(1-\mathrm{P})$;

$\mathrm{L}=$ galat yang diinginkan

Besaran sampel dengan tingkat konfidensi 95\%, galat $5 \%$, perkiraan prevalensi $5 \%$, maka diperoleh

$$
n=\frac{4 P Q}{L^{2}}=\frac{4 \times 0.5 \times 0.5}{(0.05)^{2}}=384 \text { ekor }
$$

Untuk mengurangi bias maka dilakukan perhitungan design effect (DE) terhadap hasil perhitungan di atas. Melalui perhitungan variansi antar peternakan dan variansi dalam peternakan, maka perhitungan design effect (DE) dan jumlah sampel adalah sebagai berikut:

1. Perhitungan jumlah sapi per peternakan menggunakan variansi antar dan di dalam peternakan adalah:

$$
\begin{array}{ll}
\mathrm{S}_{1}{ }^{2} & =\text { Variansi di antara peternakan (among) } \\
\mathrm{S}_{2}{ }^{2} & =\text { Variansi di dalam peternakan (within) } \\
\mathrm{P} & =5 \% \\
\mathrm{Rho}(\rho) & =0,05 \\
\mathrm{~S}^{2} & =\mathrm{P} \times \mathrm{Q} \\
\mathrm{S}^{2} & =(0,5)(0,5)=0,25 \\
\rho \quad=\mathrm{S}_{1}^{2} / \mathrm{S}^{2} \rightarrow \mathrm{S}_{1}^{2} & =\rho . \mathrm{S}^{2} \\
& =(0,05)(0,25) \\
& =0,0125 \text { (variansi antar } \\
& \text { peternakan) } \\
\mathrm{S}_{2}^{2} & =\mathrm{S}^{2}-\mathrm{S}_{1}^{2}=0,25-0,0125 \\
\mathrm{~S}_{2}^{2} & =0,2375 \text { (variansi di dalam } \\
& \text { peternakan). }
\end{array}
$$

$$
n_{p}=\sqrt{\left[\frac{S_{2}{ }^{2}}{S_{1}{ }^{2}}\right]}=\sqrt{\left[\frac{0,2375}{0,0125}\right]}=4,35
$$

Sehingga jumlah sapi yang diambil adalah 4 ekor sapi/peternakan.

Jumlah peternak yang dipilih adalah $\frac{384 \text { ekor }}{4 \text { ekor }}=96$ peternakan dan pengambilan sampel dilakukan terhadap seluruh sapi di setiap peternak (klaster).

\section{Pengambilan Sampel Darah}

Pengambilan sampel darah dilakukan pada vena coccygea sebanyak $3 \mathrm{cc}$ menggunakan tabung venoject, kemudian serum dipisahkan ke tabung mikro dan di simpan pada freezer sampai dengan pengujian Enzyme-linked Immunosorbent Assay (ELISA).

\section{Pengujian Enzyme-linked Immunosorbent Assay (ELISA)}

Preparasi sampel dan kontrol pada 96 sumuran sebelum dipindahkan ke dalam mikroplat ELISA. Preparasi cairan pencuci dicampur aquadestilata dengan perbandingan 1:20. Preparasi semua reagen pada suhu ruangan $\left(21^{\circ} \mathrm{C} \pm 5^{\circ} \mathrm{C}\right)$ dan dihomogenkan dengan vortex. Mikroplate kit ELISA disiapkan, kemudian dilakukan pengisian $25 \mu$ dilution buffer 19 ke dalam tiap sumuran. Sebanyak $25 \mu$ kontrol positif dimasukan ke dalam sumuran A1 dan B1. Sebanyak $25 \mu \mathrm{l}$ kontrol negatif ditambahkan ke dalam sumur C1 dan D1, sedangkan serum sampel dimasukkan ke dalam sumur E1 sampai seterusnya sebanyak $25 \mu \mathrm{l}$ sesuai pola yang telah dibuat. Mikroplate yang sudah diisi tersebut diinkubasi selama 45 menit \pm 5 menit pada suhu $21^{\circ} \mathrm{C} \pm 5^{\circ} \mathrm{C}$. Sumuran dikosongkan dan dicuci 3 kali menggunakan larutan pencuci (washing solution) sebanyak $300 \mu$ l. Setiap selesai tahap pencucian sangat dihindari dasar mikroplate menjadi kering dengan segera mengerjakan tahap selanjutnya. Sebanyak $100 \mu \mathrm{l}$ larutan konjugat ditambahkan ke dalam tiap sumuran dan diinkubasi selama 30 menit \pm 3 menit pada suhu $21^{\circ} \mathrm{C} \pm 5^{\circ} \mathrm{C}$. Sumuran dikosongkan kembali dan dicuci sebanyak 3 kali menggunakan larutan pencuci (washing solution) sebanyak $300 \mu$ l. Sebanyak $100 \mu \mathrm{l}$ substrat TMB ditambahkan ke dalam setiap sumuran kemudian diinkubasi selama 15 menit \pm 2 menit pada suhu $21^{\circ} \mathrm{C} \pm 5^{\circ} \mathrm{C}$ di ruangan gelap. Sebanyak 100 $\mu$ stop solution ditambahkan ke dalam setiap sumuran untuk menghentikan reaksi dan dilakukan pembacaan dengan menggunakan ELISA reader pada panjang gelombang $450 \mathrm{~nm}$.

\section{Interpretasi Hasil Pengujian ELISA Antibodi}

Sampel dengan nilai sample value related to positive value (S/P) sebesar 0,4 atau lebih menunjukkan 
adanya antibodi terhadap BVD dan hasil uji berarti positif. Perhitungan (S/N\%) dapat dihitung dengan rumus sebagai berikut:

$$
(S / N \%)=\frac{\text { Optical Density }(O D) \text { sampel }}{\text { Optical Density (OD) NC }} \times 100
$$

Untuk sampel serum, plasma dan individual milk nilai (S/N\%) memiliki beberapa interpretasi sebagai berikut:

$$
\begin{array}{ll}
\mathrm{S} / \mathrm{N} \%<40 \% & =\text { positif } \\
40 \%<\mathrm{S} / \mathrm{N} \%<50 \% & =\text { suspect } / \text { terindikasi } \\
\mathrm{S} / \mathrm{N} \%>50 \% & =\text { negatif }
\end{array}
$$

\section{Analisis Data}

Analisis data univariat dilakukan terhadap setiap variabel dan diinterpretasikan secara deskriptif. Hasil analisi univariat digunakan untuk perhitungan sero- prevalensi dan seroinsidensi. Analisis bivariate digunakan uji Chi-square $\left(\chi^{2}\right)$ untuk mengetahui signifikansi asosiasi variabel-variabel yang dikehendaki dan mengetahui kekuatan asosiasinya (odds ratio/OR) dengan tingkat kepercayaan 95\% $(\mathrm{P}<0,05)$. Data dianalisis dengan menggunakan software SPSS versi 21 lisensi Universitas Gadjah Mada.

\section{HASIL}

Deskripsi Variabel pada Peternak di Kabupaten Sleman

Gambaran peternak di Kabupaten Sleman Yogyakarta akan di jelaskan pada Tabel 1. Variabel peternak diperoleh dari kuisioner dan pengamatan

\begin{tabular}{|c|c|c|c|c|}
\hline No & Variabel & Kategori & Frekuensi & Prosentase (\%) \\
\hline \multirow[t]{5}{*}{1} & Kecamatan & Tempel & 3 & 3,1 \\
\hline & & Sleman & 31 & 32,3 \\
\hline & & Turi & 31 & 32,3 \\
\hline & & Pakem & 11 & 11,5 \\
\hline & & Cangkringan & 20 & 20,8 \\
\hline \multirow[t]{2}{*}{2} & Tipologi Peternak & Usaha Pokok & 2 & 2,2 \\
\hline & & Sambilan & 89 & 97,8 \\
\hline \multirow[t]{2}{*}{3} & Pendidikan Peternak & $\leq \mathrm{SD}$ & 62 & 67,4 \\
\hline & & $>S D$ & 30 & 32,6 \\
\hline \multirow[t]{2}{*}{4} & Jumlah Ternak & $\leq 4$ ekor & 79 & 82,3 \\
\hline & & $>4$ ekor & 17 & 17,7 \\
\hline \multirow[t]{2}{*}{5} & Kondisi Kandang & Bersih & 82 & 89,1 \\
\hline & & Kotor & 10 & 10,9 \\
\hline \multirow[t]{2}{*}{6} & Lantai Kandang & Baik & 89 & 95,7 \\
\hline & & Buruk & 4 & 4,3 \\
\hline \multirow[t]{2}{*}{7} & Cahaya Kandang & Baik & 69 & 74,2 \\
\hline & & Buruk & 24 & 25,8 \\
\hline \multirow[t]{2}{*}{8} & Pengelolaan Kotoran & Biogas & 41 & 44,1 \\
\hline & & $\begin{array}{l}\text { Di tampung disekitar } \\
\text { kandang }\end{array}$ & 52 & 55,9 \\
\hline \multirow[t]{2}{*}{9} & Tempat pakan & Terpisah & 69 & 74,2 \\
\hline & & Jadi satu & 24 & 25,8 \\
\hline \multirow[t]{2}{*}{10} & Ternak lain & Tidak ada & 90 & 97,8 \\
\hline & & Ada & 2 & 2,2 \\
\hline \multirow[t]{3}{*}{11} & Jenis ternak lain & Domba & 89 & 96,7 \\
\hline & & Kambing & 1 & 1,1 \\
\hline & & Babi & 2 & 2,2 \\
\hline \multirow[t]{2}{*}{12} & Sumber air minum untuk sapi & Air sumur & 6 & 6,5 \\
\hline & & Mata air/PAM & 87 & 93,5 \\
\hline
\end{tabular}
langsung di lapangan kemudian dianalisis secara deskriptif.

Tabel 1 Deskripsi variabel kategorik peternak di Kabupaten Sleman 


\section{Seropositif BVD}

Pengujian serologi yang diperoleh berdasarkan pengujian Enzyme-linked Immunosorbent Assay (ELISA) dari 96 sampel peternak yang diambil, terdapat 54 peternak yang memiliki sapi positif BVD. Berdasarkan hasil yang diperoleh sampel yang terdeteksi positif berasal dari 5 kecamatan yang berbeda, yaitu seperti pada Tabel 2 .

\section{Analisis Bivariat Variabel Peternak di Kabupaten Sleman}

Analisis bivariate yang digunakan adalah analisis Chi Square $\left(\chi^{2}\right)$, yaitu salah satu analisis untuk melihat hubungan (asosiasi) antar 2 variabel. Variabel peternak yang digunakan adalah masing-masing variabel yang dicantumkan dalam kuesioner dan hasil pengujian serum BVD pada sapi (positif dan negatif). Variabel yang mempunyai hubungan satu dengan yang lainnya ditunjukkan pada Tabel 3.

\section{PEMBAHASAN}

\section{Deskripsi Variabel}

Analisis deskriptif pada Tabel 2 di atas, terdapat 12 variabel pada penelitian ini yang dicantumkan dalam kuesioner. Beberapa variabel tersebut yaitu berdasarkan asal sapi, tipe peternak, pendidikan peternak, jumlah ternak yang dimiliki, dan ruang lingkup kondisi kandang peternak yang dimiliki.

Asal sapi yang diambil untuk dijadikan sampel paling banyak dari kecamatan Sleman dan kecamatan Turi, yaitu 32,3\% dengan jumlah sapi sebanyak 31 ekor. Berdasarkan asal sapi yang diperoleh dari peternak di 5 kecamatan, yaitu Kec. Tempel, Kec. Turi, Kec. Sleman, Kec. Pakem, Kec. Cangkringan, tipe peternak untuk memelihara ternak mereka adalah untuk sambilan, yaitu sebanyak 89 peternak (97,8\%). Pendidikan peternak yang berada pada 5 kecamatan tersebut mayoritas hanya menempuh maksimal
Sekolah Dasar (SD), yaitu sebanyak 62 orang $(67,4 \%)$ yang memiliki pendidikan maksimal SD dengan jumlah ternak yang dimiliki sebagian besar kurang dari 4 ekor, yaitu 79 peternak (82,3\%). Walaupun tingkat pendidikan yang dimiliki peternak mayoritas hanya SD, kondisi kandang yang dimiliki cukup bersih yaitu sebanyak 82 peternak $(89,1 \%)$ yang kondisi kandangnya bersih.

Tata kelola kandang yang baik merupakan faktor penting dalam usaha peningkatan produksi sapi perah. Kondisi kandang juga akan menentukan keadaan peternakan tersebut. Lantai kandang yang dimiliki oleh peternak di 5 Kecamatan tersebut cukup baik, yaitu 89 peternak (95,7\%) memiliki kandang dengan lantai kandang yang baik. Selain itu, cahaya kandang yang dimiliki 69 peternak $(74,2 \%)$ baik. Artinya bahwa kandang mendapatkan sinar matahari yang cukup. Sehingga kelembaban dapat terjaga dengan baik. Kandang yang terang dan cukup mendapat sinar matahari dapat mempercepat pengeringan kandang yang basah akibat urin yang mengalir, air bekas memandikan ternak dan menyemprot kandang. Kondisi kandang yang kotor pada penelitian ini hanya sekitar $10.9 \%$. Hal ini dapat menyebabkan meningkatnya kejadian mastitis dan radang teracak (foot root) pada sapi perah, kedua penyakit ini dapat menyebabkan penurunan produksi susu.

Pengelolaan kotoran yang dilakukan oleh peternak belum maksimal dilakukan pengolahan yang baik. Terdapat 52 peternak $(55,9 \%)$ yang masih mengumpulkan kotoran sapi dengan hanya ditampung saja di sekitar kandang, dan hanya 41 peternak $(44,1 \%)$ yang menjadikan kotoran tersebut sebagai biogas. Hal ini membutuhkan usaha untuk mengajarkan peternak bahwa kotoran sapi dapat digunakan untuk biogas atau pupuk yang sangat bermanfaat.

Sebanyak 69 peternak $(74,2 \%)$ telah memisahkan tempat pakan yang ada pada kandang mereka, sehingga dapat membatasi adanya kontaminasi antara

Tabel 2 Seropositif BVD di Kabupaten Sleman

\begin{tabular}{clccc}
\hline No & Kecamatan & Jumlah Peternakan & $\begin{array}{c}\text { Jumlah Positif Tingkat } \\
\text { Peternak }\end{array}$ & Persentase Positif (\%) \\
\hline 1 & Pakem & 11 & 4 & $4,2 \%$ \\
2 & Turi & 31 & 22 & $22,9 \%$ \\
3 & Sleman & 31 & 16 & $16,7 \%$ \\
4 & Cangkringan & 20 & 11 & $11,5 \%$ \\
5 & Tempel & 3 & 1 & $1 \%$ \\
\hline
\end{tabular}


Tabel 3 Analisis bivariat variabel peternak di Kabupaten Sleman

\begin{tabular}{|c|c|c|c|c|c|c|}
\hline No & Variabel & Kategori & Positif & Negative & $P_{\text {_value }}$ & OR \\
\hline \multirow[t]{5}{*}{1} & Kecamatan & Tempel & 1 & 2 & 0,247 & - \\
\hline & & Sleman & 16 & 15 & & \\
\hline & & Turi & 22 & 9 & & \\
\hline & & Pakem & 4 & 7 & & \\
\hline & & Cangkringan & 11 & 9 & & \\
\hline \multirow[t]{2}{*}{2} & Tipologi Peternak & Usaha Pokok & 1 & 1 & 0,836 & - \\
\hline & & Sambilan & 51 & 38 & & \\
\hline \multirow[t]{2}{*}{3} & Pendidikan Peternak & $\leq \mathrm{SD}$ & 34 & 28 & 0,64 & - \\
\hline & & $>\mathrm{SD}$ & 18 & 12 & & \\
\hline \multirow[t]{2}{*}{4} & Jumlah Ternak & $\leq 4$ ekor & 41 & 38 & 0,064 & - \\
\hline & & $>4$ ekor & 13 & 4 & & \\
\hline \multirow[t]{2}{*}{5} & Kondisi Kandang & Bersih & 48 & 34 & 0,264 & - \\
\hline & & Kotor & 4 & 6 & & \\
\hline \multirow[t]{2}{*}{6} & Lantai Kandang & Baik & 51 & 38 & 0,203 & - \\
\hline & & Buruk & 1 & 3 & & \\
\hline \multirow[t]{2}{*}{7} & Cahaya Kandang & Baik & 40 & 29 & 0,498 & - \\
\hline & & Buruk & 12 & 12 & & \\
\hline \multirow[t]{2}{*}{8} & Pengelolaan Kotoran & Biogas & 27 & 14 & 0,086 & - \\
\hline & & $\begin{array}{l}\text { Di tampung disekitar } \\
\text { kandang }\end{array}$ & 25 & 27 & & \\
\hline \multirow[t]{2}{*}{9} & Tempat pakan & Terpisah & 35 & 34 & 0,087 & - \\
\hline & & Jadi satu & 17 & 7 & & \\
\hline \multirow[t]{2}{*}{10} & Ternak lain & Tidak ada & 51 & 39 & 0,851 & - \\
\hline & & Ada & 1 & 1 & & \\
\hline \multirow[t]{3}{*}{11} & Jenis ternak lain & Domba & 50 & 39 & 0,241 & - \\
\hline & & Kambing & 0 & 1 & & \\
\hline & & Babi & 2 & 0 & & \\
\hline \multirow[t]{2}{*}{12} & Sumber air minum untuk sapi & Air sumur & 4 & 2 & 0,583 & - \\
\hline & & Mata air/PAM & 48 & 39 & & \\
\hline
\end{tabular}

satu hewan dengan hewan yang lainnya. Di samping itu, untuk meminimalisisr adanya penyakit yang menular antar hewan, sebanyak 90 peternak $(97,8 \%)$ tidak menjadikan satu kandang dengan ternak lain yang dipelihara. Sebagian besar peternak memiliki jenis ternak lain berupa domba. Sebanyak 89 peternak (96,7\%) memiliki domba. Sumber air minum yang digunakan oleh sapi mereka adalah berasal dari mata air/PAM, yaitu sebanyak 93,5\%.

\section{Seroprevalensi}

Identifikasi Pengujian BVD dengan menggunakan Elisa terdapat 54 ekor yang positif BVD di Kabupaten Sleman. Masing - masing kecamatan yaitu Kecamatan Pakem terdapat 4 ekor positif, Kecamatan Turi terdapat 22 ekor positif, Kecamatan Sleman 16 ekor positif, Kecamatan Cangkringan 11 ekor positif, dan Kecamatan Tempel 1 ekor positif. Seroprevalensi BVD di tingkat peternak yang terjadi di Kabupaten Sleman dapat dikategorikan cukup tinggi yaitu sebesar $56,25 \%$. Hal ini perlu mendapatkan perhatian khusus dari berbagai pihak untuk memberikan sosialisasi atau penyuluhan kepada peternak untuk menjaga kondisi ternak maupun kondisi lingkungan. Perhatian tersebut dapat didukung dengan adanya kebijakan vaksinasi BVD di Indonesia, karena tingkat seroprevalensi dapat mengindikasikan bahwa infeksi virus BVD dapat memicu terbentuknya antibodi BVD. Menurut penelitian Swasthikawati (2015) menyatakan bahwa infeksi virus BVD di Indonesia merupakan akibat dari infeksi alami.

\section{Analisis Bivariat}

Analisis variabel yang digunakan untuk mengetahui asosiasi/hubungan antara variabel independen dengan hasil pengujian BVD adalah dengan menggunakan analisis bivariate yaitu analisis ChiSquare $\left(\chi^{2}\right)$. Hasil pada Tabel 3 menunjukkan bahwa tidak terdapat hubungan antara variabel kategorik 
peternak dengan hasil pengujian BVD. Hal ini ditunjukkan nilai $p_{-}$value $>0.05$ sehingga analisis tidak dapat dilanjutkan dengan menghitung nilai odd ratio (OR) untuk melihat kekuatan resiko.

Variabel tipologi peternak yang berupa usaha pokok dan sambilan menunjukkan bahwa tidak ada hubungan antara tipologi peternak dengan seropositif BVD. Uji Chi-Square antara variabel tipologi peternak dan seropositif BVD menunjukkan nilai P_value yaitu 0.836 sehingga dapat disimpulkan bahwa tidak ada hubungan bermakna antara tipologi peternak dan seropositif BVD. Hal ini berbeda dengan penelitian Milián-suazo (2016) bahwa tipologi peternakan berpengaruh terhadap seropositif BVD. Variabel pendidikan peternak ( $\leq$ SD dan > SD) menunjukkan bahwa tidak terdapat hubungan dengan seropositif BVD. Hal ini ditunjukkan dengan hasil uji Chi-Square antara pendidikan peternak dengan seropositif BVD memiliki nilai p_value yaitu 0.64. Variabel jumlah ternak ( $\leq 4$ ekor dan $>4$ ekor) menunjukkan tidak terdapat hubungan dengan seropositif BVD. Hal ini ditunjukkan dengan hasil uji Chi-Square antara jumlah ternak dengan seropositif BVD yang memiliki nilai $p_{-}$value yaitu 0.064 .

Variabel kondisi kandang (bersih dan kotor), lantai kandang (baik dan buruk), cahaya kandang (baik dan buruk), pengelolaan kotoran (biogas dan ditampung disekitar kandang), tempat pakan (terpisah dan jadi satu) menunjukkan tidak terdapat hubungan dengan seropositif BVD. Hal ini ditunjukkan secara berturut turut hasil uji Chi-Square antara variabel - variabel tersebut dengan seropositif BVD yang memiliki nilai $p_{\text {_value }}$ yaitu $0.264,0.203,0.498$, 0.086, 0.087 (p_value > 0.05). Berdasarkan penelitian Primawidyawan (2016) terdapat hubungan antara faktor program pengolahan limbah yang ada pada peternakan dengan kejadian penyakit BVD. Hal ini berbanding terbalik dengan penelitian yang telah dilakukan.

Variabel ternak lain (ada dan tidak ada), jenis ternak lain (domba, kambing dan babi) tidak menunjukkan hubungan dengan seropositive BVD. Hal ini ditunjukkan dengan uji Chi-Square secara berturut turut memiliki nilai $p_{-}$value yaitu 0.851 dan 0.241 ( $p_{-}$value $>0.05$ ). Penelitian ini berbeda dengan penelitian Krametter et al. (2010) yang menyatakan bahwa BVD dapat ditularkan oleh domba dan kambing ke ternak sapi, yang ditunjukkan dengan nilai prevalensi domba dan kambing PI sebesar 0,32\% dan $0,08 \%$

Variabel sumber air minum untuk sapi (air sumur dan air PAM) tidak menunjukkan hubungan dengan seropositive BVD. Hal ini ditunjukkan dengan nilai

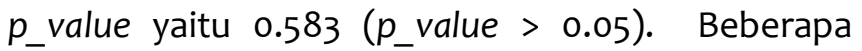
faktor yang menyebabkan terjadinya perbedaan seroprevalensi BVD adalah kondisi stress ternak, tingkat dehidrasi, pemberian pakan, kontrol lingkungan, temperatur, dan biosekuriti serta yang paling penting adalah penyebaran infeksi pada sapi dan domba dalam satu peternakan yang sama (Bolin 1990; Luzzago et al. 2010; Brodersen 2010; Khezri 2015).

\section{UCAPAN TERIMA KASIH}

Penelitian ini dibiayai melalui Hibah Penelitian Departemen Fakultas Kedokteran Hewan Universitas Gadjah Mada. Penulis mengucapkan terima kasih yang sebesar-besarnya kepada Lembaga Penelitian dan Pengabdian Masyarakat Universitas Gadjah Mada.

"Penulis menyatakan tidak ada konflik kepentingan dengan pihak-pihak yang terkait dalam penelitian ini".

\section{DAFTAR PUSTAKA}

Baker JC. 1990. Clinical aspects of bovine virus diarrhoea virus infection. Revue Scientifique et Technique Office International of Epizootics. 9(1): 25-41.

Baker JC. 1995. The clinical manifestations of bovine viral diarrhea infection. Veterinary Clinics of North America: Food Animal Practice. 11(3): 425-445. http://doi.org/10.1016/S0749-0720(15)30460-6

Bolin SR. 1990. The current understanding about the pathogenesis and clinical forms of BVD. Veterinary Medicine. 85: 1124-1132.

BPS. 2015. Statistik Daerah Kabupaten Sleman 2015. Badan Pusat Statistik Kabupaten Sleman. Yogyakarta.

BPS.

2018.

https://www.bps.go.id/dynamictable/2015/12/17/1 018/populasi-sapi-perah-menurut-provinsi-20092017.html (diakses tanggal 15 Oktober 2018).

Brodersen BW. 2010. Bovine respiratory syncytial virus. Veterinary Clinics of North America: Food Animal Practice. 26: 323-333.

Fray MD, Paton DJ, Alenius S. 2000. The effects of bovine viral diarrhoea virus on cattle reproduction in relation to disease control. Animal Reproduction Science. 60-61, 615-627. 
Houe H. 2003. Economic impact of BVDV infection in dairies. Journal Biologicals. 31: 137-143. http://doi.org/10.1016/S1045-1056(03)00030-7.

Khezri, Mohammad. 2015. Bovine Viral Diarrhea (BVD): A review emphasizing on Iran perspective. Journal of Advance and Veterinary Animal Research. 2(3): 240-251. http://bdvets.org/JAVAR

Krametter-FroetScher $R$, Duenser $M$, Preyler $B$, Theiner A, Benetka V, Moestl K, Baumgartner,W. 2010. Pestivirus infection in sheep and goats in West Austria. Vet J.186: 342-346.

Lanyon SR, HillS FI, Reichel MP, Brownlie J. 2014. Bovine viral diarrhoea: Pathogenesis and diagnosis. Vet J. 199 (2): 201-9. Available from: http://dx.doi.org/10.1016/j.tvjl.2013.07.024

Lindberg A, Houe H. 2005. Characteristics in the epidemiology of Bovine Viral Diarrhea Virus (BVDV) of relevance to control. Prev Vet Med. 72(1-2): 55-73.

Luzzago C, Bronzo V, Salvetti S, Frigerio M, Ferrari N. 2010. Bovine respiratory syncytial virus seroprevalence and risk factors in endemic dairy cattle herds. Veterinary Research Communications. 34: 19-24.

Marques ALA, Assis AC de O, Simões SVD, Tolentino MLD de L, Azevedo SS de. 2016. Risk factors associated with Bovine Viral Diarrhea Virus (BVDV) infection in the semiarid of the state of Paraíba, in the northeast region of Brazil. Semin Ciências Agrárias. 37(5):3095. Available from: http://www.uel.br/revistas/uel/index.php/semagr arias/article/view/22493
Milián-suazo F, Hernández-ortíz R, Hernándezandrade L, Díaz-aparicio E, Mejía-estrada F, Palomares-reséndiz EG, Reyes IB, Zendejasmartínez H. 2016. Seroprevalence and risk factors for reproductive diseases in dairy cattle in Mexico, 8(August). 89-98. http://doi.org/10.5897/JVMAH2016.0483.

Niskanen R, Emanuelsonb U, Sundberg J, Larssond B, Alenius S. 1995. Effects of infection with Bovine Virus Diarrhoea Virus on health and reproductive performance in 213 dairy herds in one county in Sweden. Preventive Veterinary Medicine. 23(94): 229-237.

Primawidyawan A, Indrawati A, Lukman DW. 2016. Deteksi penyakit Bovine Viral Diarrhea pada sapi potong impor melalui pelabuhan tanjung priok. Acta Veterinaria Indonesiana ISSN 2337-3202, EISSN 2337-4373. 4(1): 7-13, Januari 2016. http://www.journal.ipb.ac.id/indeks.php/actaveti ndones.

Ridpath JF. 2003. BVDV genotypes and biotypes: Practical Implications for Diagnosis and Control. Biologicals. $\quad 31(2): \quad$ 127-131. http://doi.org/10.1016/S1045-1056(03)00028-9

Swasthikawati S. 2015. Identifikasi dan Diferensiasi Infeksi Virus Bovine Viral Diarrhea Secara Serologis. Universitas Gadjah Mada.

Weersink A, Vanleeuwen JA, Chi J, Keefe GP. 2002. Direct Production Losses and Treatment Costs due to Four Dairy Cattle Diseases. 14: 55-75. 